Article

\title{
The Importance Placed on the Monitoring of Food Safety and Quality by Australian Consumers
}

\author{
Julie Henderson $^{1, *}$, Loreen Mamerow ${ }^{2}$, Anne W. Taylor ${ }^{3}$, Paul R. Ward ${ }^{2}$, \\ Samantha B. Meyer ${ }^{2}$ and John Coveney ${ }^{2}$
}

1 School of Nursing \& Midwifery, Flinders University; Box 2100, Adelaide 5001, Australia

2 Discipline of Public Health, Flinders University; Box 2100, Adelaide 5001, Australia; E-Mails: Paul.Ward@flinders.edu.au (P.R.W.); Samantha.Meyer@flinders.edu.au (S.B.M.); head.fppphc@flinders.edu.au (J.C.)

3 Population Research and Outcome Studies, The University of Adelaide; Adelaide 5005, Australia; E-Mail: Anne.Taylor@Adelaide.edu.au

* Author to whom correspondence should be addressed; E-Mail: Julie.Henderson@flinders.edu.au; Tel.: +61-8-8201-7638; Fax: +61-8-8276-1602.

Received: 27 March 2013; in revised form: 14 May 2013 / Accepted: 23 May 2013 / Published: 27 May 2013

\begin{abstract}
Food Standards Australia New Zealand (FSANZ) estimates that Australians experience 5.4 million incidents of food poisoning each year, making food safety a significant public health issue. This paper describes and analyses the importance placed by Australians on the role of the agencies and actors that regulate the safety and quality of food. A computer assisted telephone interviewing survey addressing aspect of food safety was administrated to a random sample of 1,109 participants across all Australian states (response rate $41.2 \%$ ). Only $44.6 \%$ of participants viewed the monitoring of food safety and quality as 'Very important', with greatest significance placed upon personal monitoring (76.0\%) and the role of the Federal government (51.1\%). The media (22.5\%) and local council (32.4\%) were viewed as the least important agents. When data were combined to create an index of general monitoring, participants under 30; respondents in outer regional areas; and men identified food monitoring as less important; while respondents from households with 5 or more members viewed food monitoring as more important than respondents from smaller households.
\end{abstract}

Keywords: food safety; food regulation; survey; public health; Australia 


\section{Introduction}

Food safety is a major public health issue. Mead et al. estimate that known food borne pathogens account for 60,000 hospitalisations in the US annually [1]. Incidents of illnesses arising from food borne pathogens are rising. Bentham and Langford argue that changes in food storage and patterns of consumption e.g., consumption of more white meat; the ageing of the population; and greater consumption of food prepared outside of the home are all factors in increasing rates of food poisoning. Similar trends are evident in Australia [2]. Food Standards Australia New Zealand (FSANZ) estimate that 11,500 new cases of food poisoning occur daily with 120 Australians dying of food poisoning annually [3]. Despite this, the public underestimates the risks associated with poor food hygiene. Notwithstanding the belief that personal food safety habits will prevent the risk of food poisoning [4] there is also a belief that governments at all levels should be playing a role in increasing food safety by regular monitoring of the food supply [5,6].

Globally, there have been marked changes in approaches to food regulation from the 1990s [7,8]. Many factors such as major food scares, increasing food importation and the emergence of new food technologies have contributed to an increased focus upon food regulation and greater consumer expectations that the food they purchase is safe to eat [7,9-11]. In response, new forms of food safety regulation are being explored; the focus of which is upon self-regulation and co-regulation [12]. Caduff and Bernauer note a trend towards multi-level governance of food alongside of increasing industry self-regulation of food safety and the development of voluntary industry codes of practice $[7,13]$. At the core of industry self-regulation is risk analysis of food production $[7,13,14]$. One measure is the introduction of Hazard Analysis and Critical Control Point (HACCP) systems which manage microbial issues through identification and monitoring of hazards by the food industry. Another strategy is the development of standards for producers and retailers by industry, for example the British Retail Consortium (BRC) standards developed for monitoring food safety in UK supermarkets [15].

\section{Food Regulation in Australia}

Food regulation in Australia occurs over multiple levels of governance [16]. The responsibilities of the Federal government include the establishment of standards; importation restrictions and quarantine; and food labelling. State and Territory governments enact food legislation and implement and enforce standards while food inspection is managed by local councils [16-18]. The establishment of food standards is the responsibility of Food Standards Australia New Zealand (FSANZ), a bi-national semi-governmental regulatory agency that was established in December 2002 [19]. The regulation of food safety has two competing and often contradictory aims: the protection of public health but also the regulation of the market to ensure fair competition [20]. FSANZ was established in response to changes in the types of foods in the food supply [16], inconsistencies in food standards across state jurisdictions [21-23], increasing incidence of food borne illness and poor compliance with World Trade Organization treaties governing food safety and free trade which require that Australia ensure protection of public health without restricting trade [22]. FSANZ adopted a preventative approach to food safety reflected in legislation which defined what should be achieved rather than how it should be 
achieved [22]. This approach is evident in a movement from standards for specific foods to more general standards applying across food groups which were designed to encourage innovation through reducing regulation [23] but also in a requirement that the food industry adopt HACCP systems to identify and manage potential food hazards [21]. The second is an example of move towards co-regulation of food production methods and greater self-regulation of food hygiene by the food manufacturing industry $[17,19]$.

Existing research suggests that while Australians have limited understanding of food governance they maintain a strong expectation of the role of government in managing food safety [24,25]. Buchler et al. in a national survey of food risks and regulation found that there was a perception that government could do more to ensure food safety [6]. As such, many participants indicated a need for further governmental regulation. Existing research suggests that there are demographic differences in knowledge of and concern about food safety. People from higher socio-economic status are more likely to draw upon existing knowledge in drawing conclusions about food safety issues due to education [26]. Higher levels of education have also been linked to use of government and scientific information sources rather than social networks in making these decisions [27]. Age has been found to be associated with interest in and concerns with food safety with younger participants displaying less interest in or knowledge of food issues [28,29]. Likewise, gender has been related to concerns with food issues with women displaying greater concern about the safety of specific products and with environmental issues $[29,30]$. What is not known is how demographic factors impact the importance placed on food monitoring. The present study examines the importance placed by Australians on the monitoring of food safety. The study extends findings from a national survey on public perceptions of food trust undertaken as part of the "Food and Trust" study [31,32]. This study primarily identified the nature and level of consumer trust in the Australian food supply and is based on a similar survey undertaken in Europe [30]. Questions in the survey explored awareness of and trust placed in food regulation; acceptance of food risk and trust in other institutions including government. Data for this paper was drawn from questions exploring the importance placed on food regulation. It offered a unique opportunity to gain insight into Australians' opinions regarding the importance of monitoring and regulation of food, focusing on predictive demographic factors. The specific aim of this paper therefore, is to examine the impact of demographic characteristics upon public views of agencies and actors in the food chain and their role in monitoring the safety of the food supply.

\section{Method}

Households in Australia with a telephone connected and the telephone number listed in the Australian electronic white pages (EWP) were eligible for random selection in the sample for this study. The person, aged 18 years or over, who was last to have a birthday, was randomly selected within each contacted household to complete the survey. Professional interviewers conducted the study using Computer Assisted Telephone Interview (CATI) methodology from October to December 2009. A minimum of 10 call-backs were made to the telephone numbers selected, to interview household members and different times of the day or evening were scheduled for each call-back. Non-contactable or responding persons were not replaced with other respondents. 
Of the initial sample of 4,100, a sample loss of 1,408 occurred due to non-connected numbers ( $n=1,060)$, non-residential numbers $(n=135)$, ineligible households $(n=139)$, and fax/modem connections $(n=74)$, leaving 2692 phone numbers eligible for survey phone calls. After refusals, terminated interviews, non-contactable households, deaths, unavailable respondents and respondents who could not speak English, 1,109 interviews were completed. This generated an overall sample response rate of $41.2 \%$. As samples such as these may be disproportionate with respect to the population of interest, weighting was used to compensate for differential non-response and correct unequal sample inclusion probabilities. In order to reflect the Australian population structure 18 years and over, the data were weighted by age and sex reflecting the Australian Bureau of Statistics 2007 Estimated Residential Population.

Of particular relevance to the current investigation were several survey items addressing the importance placed upon the monitoring of food safety and quality by external bodies. The relevant survey questions were framed as follows: 'In terms of monitoring the safety and quality of food, how important are the following?' Survey participants rated the importance of monitoring performed by several external bodies, including:

- Food scientists

- Consumer organizations (like Choice and the Heart Foundation)

- The press, radio and television

- Local council

- State Government

- Federal Government

In addition to evaluating the importance of monitoring carried out by the aforementioned agents, respondents were also asked how they perceived their own role in monitoring food safety and quality. Demographic variables entered into the present analysis included age, sex, number of people in the household, number of children under 18 years of age in the household, marital status, work status, education, annual household income, the Socio-Economic Indexes for Areas (SEIFA) Index of Relative Socio-Economic Disadvantage (IRSD) as well as the Accessibility/Remoteness Index of Australia (ARIA).

\section{Data Analyses}

All statistical analyses reported in this report were carried out using the statistical software package SPSS version 17.0. For analytical purposes, all outcome variables (i.e., the seven items addressing the importance of monitoring) were dichotomised. The original question asked participants to indicate whether they viewed each form of food regulation to be "Not important', “Quite important' or "Very important'. In order to obtain viable cell frequencies for analysis, responses in the form of 'Not important' and 'Quite important' were combined to create one level of the outcome variable ('Not very important'), while responses indicating the respondent considered different kinds of monitoring 'Very important' generated the second outcome level. 'Don’t know' responses as well as refusals to answer a question were not included in the present analysis. 
Information on respondent's demographic characteristics was entered into the analysis in the form of categorical variables, the individual levels of which are summarized in Table 1. Bivariate logistic regression analyses were performed to examine the relationship between the individual demographic predictors and the importance placed upon the monitoring of food safety and quality by various agents. Only items showing an association at the $p<0.25$ level were entered into multiple binary logistic regression analyses [33]. Following suggestions by Field, for the purposes of the present investigation, the method of choice for conducting regression analyses was to enter relevant predictor variables in one block rather than stepwise procedures. Predictor variables that were entered into the model but returned as not significant were in turn tested against models containing only significant predictor variables [34]. This process allowed for the comparison of several models, resulting in a final model for every outcome variable containing only variables that significantly improved the fit of the model. For each outcome variable, predictor variables included in the regression model were checked for multicollinearity.

In addition, a multiple index based upon results received for the importance placed on food monitoring for the items as a whole was constructed. This was facilitated by generating a binary index for every participant based on that person's mode of dichotomized responses for the separate monitoring variables. Thus, if an individual replied 'Not very important' more often than 'Very important' across the separate monitoring items, this person's position on food safety and quality monitoring in general would be summarized accordingly (i.e., 'Not very important').

Table 1. Demographic profile of respondents.

\begin{tabular}{lc}
\hline Demographic predictor variables & N (\%) \\
\hline Age & $249(22.5)$ \\
Under 30 years & $326(29.4)$ \\
30-44 years & $272(24.6)$ \\
45-59 years & $261(23.5)$ \\
60 years and over & \\
Sex & $547(49.3)$ \\
Male & $562(50.7)$ \\
Female & \\
People in household & $177(16.0)$ \\
One person household & $346(31.2)$ \\
Two people in the household & $403(36.4)$ \\
Three to four people in the household & $183(16.5)$ \\
Five or more people in the household & \\
Children under 18 in household & $674(60.8)$ \\
None & $166(15.0)$ \\
One & $169(15.3)$ \\
Two & $100(9.0)$ \\
Three or more & \\
Marital status & $665(59.9)$ \\
Married/Living with partner & $149(13.5)$ \\
Separated/Divorced/Widowed & $293(26.4)$ \\
Never married &
\end{tabular}


Table 1. Cont.

\begin{tabular}{lc}
\hline Demographic predictor variables & $\mathrm{N}(\%)$ \\
\hline Work status & \\
Full time employed & $507(45.8)$ \\
Part time employed/Unemployed & $228(20.6)$ \\
Economically inactive (home duties, student, & $372(33.6)$ \\
retired, etc.) & \\
Education & $490(44.2)$ \\
Secondary & $345(31.1)$ \\
Trade, certificate, diploma & $274(24.7)$ \\
Degree or higher & \\
Annual household income & $212(22.6)$ \\
Up to \$30,000 & $231(24.6)$ \\
\$30,001-\$60,000 & $253(27.0)$ \\
\$60,001-\$100,000 & $243(25.9)$ \\
\$100,001 or more & \\
SEIFA (IRSD) & \\
Lowest quintile & $201(18.1)$ \\
Low quintile & $266(24.0)$ \\
Middle quintile & $218(19.7)$ \\
High quintile & $212(19.2)$ \\
Highest quintile & $211(19.1)$ \\
ARIA & \\
Major cities & $627(56.5)$ \\
Inner regional & $293(26.4)$ \\
Outer regional & $156(14.1)$ \\
(Very) Remote & $33(3.0)$ \\
\hline
\end{tabular}

\section{Results}

\subsection{Importance of Monitoring the Safety and Quality of Food}

Examination of participants' response patterns for all monitoring variables yielded some interesting results regarding the importance placed upon agents' monitoring of food safety and quality (Table 2). Only two items elicited 'Very important' from the majority of survey participants, namely monitoring by the federal government (51.1\%) and respondents' own monitoring (76\%). For all other monitoring performed by different agents, the majority of respondents indicated such monitoring to be 'Not very important' (55.4\%). The importance of food safety and quality monitoring in general was examined through the monitoring index. As was to be expected, response frequencies for the combined index mirrored the results for the separate items. Of participants, 59.3\% more frequently stated monitoring by all sources to be 'Not very important', compared to $40.7 \%$ who more often stated such monitoring to be 'Very important'. 
Table 2. Summary of sample size and response patterns by survey item.

\begin{tabular}{lcc}
\hline $\begin{array}{l}\text { Survey item } \\
\text { 'In terms of monitoring the safety and quality of food, } \\
\text { how important are the following?' }\end{array}$ & $\begin{array}{c}\text { 'Not very } \\
\text { important', } \\
\mathbf{N}(\%)\end{array}$ & $\begin{array}{c}\text { 'Very } \\
\text { important' } \\
\text { N (\%) }\end{array}$ \\
\hline Food scientists & $622(59.9)$ & $416(40.1)$ \\
Consumer organisations & $579(52.4)$ & $526(47.6)$ \\
Media & $849(77.5)$ & $246(22.5)$ \\
Local council & $716(67.6)$ & $343(32.4)$ \\
State government & $619(57.3)$ & $461(42.7)$ \\
Federal government & $524(48.9)$ & $548(51.1)$ \\
Personal monitoring & $265(24.0)$ & $840(76.0)$ \\
Binary index of all monitoring & $648(59.3)$ & $444(40.7)$ \\
Mean (separate items only) & $\mathbf{5 9 6 ( 5 5 . 4 )}$ & $\mathbf{4 8 3 ( 4 4 . 6 )}$ \\
\hline
\end{tabular}

\subsection{Demographic Indicators for the Importance of Food Safety and Quality Monitoring}

This paper reports the results of the multiple binary logistic regression analyses only. Across all models, marital status had no predictive qualities, hence has been omitted from the results. Odds ratios for the impact of demographic characteristics on the importance placed on food monitoring are summarized in Table 3.

Table 3. Odd ratios of significant variables for importance placed on food monitoring (monitoring index).

\begin{tabular}{lc}
\hline Importance of monitoring by: & $\begin{array}{c}\text { Monitoring Index } \\
\text { OR, }(\mathbf{9 5 \%} \mathbf{C I}), \text { significance }\end{array}$ \\
\hline Sex (Male) & $1.5(1.2-1.9)$ \\
$\quad$ Female & \\
\hline Age (Under 30 years) & $2.3(1.5-3.4)^{* * *}$ \\
$\quad$ 30-44 years & $2.7(1.8-4.1)^{* * *}$ \\
45-59 years & $3.2(2.1-5.0)^{* * *}$ \\
60+ years & \\
\hline \# People in household (Single person household) & $1.1(0.8-1.6)$ \\
2 & $1.4(0.9-2.3)$ \\
$3-4$ & $2.9(1.6-5.6) * *$ \\
$5+$ & \\
\hline \# Children in household (None) & $0.7(0.5-1.1)$ \\
One & $0.5(0.3-0.8)^{* *}$ \\
Two & $0.2(0.1-0.4)^{* * *}$ \\
Three or more & \\
\hline ARIA (Major cities) & $0.8(0.6-1.1)$ \\
Inner regional & $0.4(0.3-0.7)^{* * *}$ \\
Outer regional & $0.7(0.4-1.6)$ \\
\hline Very) Remote & \\
\hline
\end{tabular}

Note: ${ }^{* * *} p$ significant at $<0.001 ;{ }^{* *} p$ significant at 0.01 ; $p$ significant at 0.05 ; Brackets after predictor variables indicate variable reference level for regression analysis. 
Multiple variables emerged as significant indicators of the importance placed upon monitoring in general, including sex, age, the number of people and children in the household as well as ARIA. The odds of women responding "very important" were $50 \%$ higher than the odds of male respondents to deem monitoring in general "very important" $(\mathrm{OR}=1.5, p<0.01)$. The proportion of people viewing food monitoring as important was also greater among participants over 30 years compared with participants less than 30 years of age and increased as age increased. The number of people in the household was revealed to be positively associated with attributing importance to all monitoring agencies. In contrast, respondents residing in areas categorized as outer regional areas were less likely to report food monitoring in general as 'very important' ( $\mathrm{OR}=0.4, p<0.001)$ than those living in major cities.

Table 4 presents predictor variables for the importance placed on role of the different agencies and government in monitoring food safety as well as the importance placed on personal monitoring of food safety. Individual variables revealed to be significant indicators for the importance of monitoring by food scientists were age, annual household income, IRSD as well as ARIA. The predictors, which contributed significantly to the improved fit of the model for monitoring by consumer organizations, were respondents' sex, age, the number of children in the household, work status and ARIA. The two variables which contributed significantly to the variance observed in respondents' view on the importance of the media for monitoring food safety and quality were individuals' age and the number of children cohabiting in the respondent's household. Three demographic variables were returned as significant predictors for the importance of food safety and quality monitoring by the local council, namely age, work status and ARIA. Respondents' work status emerged as a significant predictor for the importance of food safety and quality monitoring by the state government, while information on the remoteness of individuals' residence (ARIA) approached significance as a predictor. Three variables on respondents' background showed significant predictive qualities for the importance placed upon the Federal Government as an agent for food safety and quality monitoring, namely the number of children in the household, work status and ARIA. Finally, several predictor variables were revealed as contributing significantly to the model for the importance attributed to respondents' personal monitoring of food safety and quality, including participants' sex, age, the number of people cohabiting within the same household, education and household income. 
Table 4. Regression analysis for seven different agencies by socio-demographic variables.

\begin{tabular}{|c|c|c|c|c|c|c|c|}
\hline $\begin{array}{l}\text { Importance of } \\
\text { monitoring by: }\end{array}$ & $\begin{array}{l}\text { Food Scientists } \\
\text { OR }(95 \% \text { CI) }\end{array}$ & $\begin{array}{l}\text { Consumer } \\
\text { Organs. } \\
\text { OR }(95 \% \text { CI }) \\
\end{array}$ & $\begin{array}{l}\text { Local Council } \\
\text { OR }(95 \% \text { CI })\end{array}$ & $\begin{array}{l}\text { Media } \\
\text { OR }(95 \% \text { CI) }\end{array}$ & $\begin{array}{l}\text { State Govt } \\
\text { OR }(95 \% \text { CI) }\end{array}$ & $\begin{array}{l}\text { Federal Govt } \\
\text { OR }(95 \% \text { CI) }\end{array}$ & $\begin{array}{l}\text { Personal } \\
\text { Monitoring } \\
\text { OR (95\% CI) } \\
\end{array}$ \\
\hline Model fit: $\chi^{2}$ (df) & $78.3(13) * * *$ & $70.2(12) * * *$ & $46.8(8) * * *$ & $19.3(6) * *$ & $32.0(5) * * *$ & $42.3(8) * * *$ & $60.8(12) * * *$ \\
\hline $\begin{array}{l}\text { Sex (Male) } \\
\text { Female }\end{array}$ & & $1.8(1.4-2.3)$ & & & & & $1.9(1.4-2.7)$ \\
\hline $\begin{array}{l}\text { Age } \\
\text { (Under } 30 \text { years) }\end{array}$ & & & & & & & \\
\hline 30-44 years & $2.9 * * *(1.8-4.5)$ & $1.7 * *(1.2-2.5)$ & $2.1 * * *(1.4-3.2)$ & $2.0 * *(1.3-3.1)$ & & & $1.5(*)(1.0-2.3)$ \\
\hline 45-59 years & $3.1 * * *(1.9-4.9)$ & $1.6 *(1.1-2.3)$ & $2.7 * * *(1.7-4.1)$ & $1.2(0.8-1.9)$ & & & $2.0 * *(1.3-3.3)$ \\
\hline $60+$ years & $3.8^{* * *}(2.3-6.2)$ & $1.2(0.8-1.7)$ & $2.5^{* * *}(1.6-3.9)$ & $1.3(0.8-2.1)$ & & & $1.8 *(1.1-3.1)$ \\
\hline $\begin{array}{l}\text { \# People in } \\
\text { household } \\
\text { (Single person } \\
\text { household) } \\
\quad 2 \\
3-4 \\
5+\end{array}$ & & & & & & & $\begin{array}{l}2.5^{* * *}(1.6-4.1) \\
1.9^{*}(1.2-3.1) \\
1.7\left(^{*}\right)(0.9-3.0)\end{array}$ \\
\hline $\begin{array}{l}\text { \# Children in } \\
\text { household (None) } \\
\text { One } \\
\text { Two } \\
\text { Three or more } \\
\end{array}$ & & $\begin{array}{l}0.9(0.6-1.3) \\
0.5^{* *}(0.3-0.8) \\
0.7(0.4-1.1)\end{array}$ & & $\begin{array}{l}0.6^{*}(0.4-0.9) \\
0.7(0.4-1.0) \\
0.4 * *(0.2-0.7)\end{array}$ & & $\begin{array}{l}1.3(0.9-1.9) \\
0.8(0.5-1.1) \\
0.5 * *(0.3-0.8)\end{array}$ & \\
\hline $\begin{array}{l}\text { Work status (Full } \\
\text { time employment) } \\
\text { Part time/ } \\
\text { Unemployed } \\
\text { Economically } \\
\text { inactive } \\
\end{array}$ & & $\begin{array}{l}0.9(0.7-1.3) \\
1.7 * *(1.2-2.3)\end{array}$ & $\begin{array}{l}0.9(0.7-1.3) \\
1.6 *(1.1-2.2)\end{array}$ & & $\begin{array}{l}1.2(0.9-1.7) \\
2.0 * * *(1.5-2.6)\end{array}$ & $\begin{array}{l}1.2(0.9-1.7) \\
1.6 * *(1.2-2.1)\end{array}$ & \\
\hline
\end{tabular}


Table 4. Cont.

\begin{tabular}{|c|c|c|c|c|c|c|c|}
\hline $\begin{array}{l}\text { Importance of } \\
\text { monitoring by: }\end{array}$ & $\begin{array}{l}\text { Food Scientists } \\
\text { OR (95\% CI) }\end{array}$ & $\begin{array}{l}\text { Consumer } \\
\text { Organs. } \\
\text { OR }(95 \% \text { CI }) \\
\end{array}$ & $\begin{array}{l}\text { Local Council } \\
\text { OR }(95 \% \mathrm{CI})\end{array}$ & $\begin{array}{l}\text { Media } \\
\text { OR }(95 \% \text { CI) }\end{array}$ & $\begin{array}{l}\text { State Govt } \\
\text { OR }(95 \% \text { CI })\end{array}$ & $\begin{array}{l}\text { Federal Govt } \\
\text { OR }(95 \% \text { CI })\end{array}$ & $\begin{array}{l}\text { Personal } \\
\text { Monitoring } \\
\text { OR (95\% CI) }\end{array}$ \\
\hline $\begin{array}{l}\text { Education } \\
\text { ( } \leq \text { secondary) } \\
\text { Trade, certificate, } \\
\text { diploma } \\
\text { Degree or higher }\end{array}$ & & & & & & & $\begin{array}{l}1.6 *(1.1-2.4) \\
1.4(0.9-2.1)\end{array}$ \\
\hline $\begin{array}{l}\text { Household income } \\
(<\mathbf{\$ 3 0 , 0 0 0 )} \\
\quad \$ 30,001-\$ 60,000 \\
\$ 60,001- \\
\$ 100,000 \\
>\$ 100,001 \\
\end{array}$ & $\begin{array}{l}0.6 *(0.4-0.9) \\
0.5 * *(0.3-0.8) \\
0.5 * *(0.3-0.8)\end{array}$ & & & & & & $\begin{array}{l}1.4(0.8-2.3) \\
0.6^{*}(0.4-0.9) \\
0.9(0.5-1.6)\end{array}$ \\
\hline $\begin{array}{l}\text { IRSD } \\
\text { (Lowest quintile) } \\
\text { Low quintile } \\
\text { Middle quintile } \\
\text { High quintile } \\
\text { Highest quintile }\end{array}$ & $\begin{array}{l}0.8(0.5-1.3) \\
1.7^{*}(1.1-2.7) \\
1.1(0.7-1.7) \\
1.3(0.8-2.3) \\
\end{array}$ & & & & & & \\
\hline $\begin{array}{l}\text { ARIA } \\
\text { (Major cities) } \\
\quad \text { Inner regional } \\
\text { Outer regional } \\
\text { (Very) Remote }\end{array}$ & $\begin{array}{l}0.8(0.6-1.2) \\
0.8(0.5-1.2) \\
2.7 *(1.1-6.5)\end{array}$ & $\begin{array}{l}0.9(0.7-1.3) \\
0.7(0.5-1.0) \\
2.3 *(1.1-5.2)\end{array}$ & $\begin{array}{l}0.9(0.7-1.3) \\
0.6 *(0.4-0.9) \\
0.5(0.2-1.1)\end{array}$ & & $\begin{array}{l}0.8\left(^{*}\right)(0.6-1.0) \\
0.7 *(0.5-0.9) \\
0.7(0.3-1.4)\end{array}$ & $\begin{array}{l}0.6 * *(0.5-0.8) \\
0.6 * *(0.4-0.9) \\
0.7(0.3-1.5)\end{array}$ & \\
\hline
\end{tabular}

Note: ${ }^{* * *} p$ significant at $<0.001 ; * * p$ significant at $0.01 ; * p$ significant at 0.05 ; Brackets after predictor variables indicate variable reference level for regression analysis. 


\section{Discussion}

In general, food safety was viewed as being 'Very important' by $44.6 \%$ of participants across all separate monitoring items. Greatest importance was placed upon personal monitoring of food safety which was viewed as 'Very important' by $76 \%$ of participants. These findings reflect those of Redmond and Griffith who found that $90 \%$ of their respondents considered themselves at low risk of food poisoning from self-prepared food [4]. Wilcock et al. found that food spoilage was frequently identified as the most important aspect of food safety [35]. Food spoilage occurs in the storage, processing and preparation of food and is therefore, amenable to individual identification and management [6]. This is reflected in public health campaigns which promote safe food handling practices within the home and may account for the importance placed on personal monitoring.

The role of the Federal government was also identified as being 'Very important' by these respondents (55.1\%) an interesting finding given trends towards co-regulation of the food. State (42.7\%) and Local governments (32.4\%) were viewed as having a less importance. This is contrary to expectations as the role of Federal government is largely limited to the establishment of standards with the monitoring of food safety standards undertaken by State and Local government $[16,18]$ however is in line with findings from a recent qualitative study which associated responsibility for food safety with the Federal Government and with the Departments of Health of state governments [25]. The importance placed on Federal government may reflect lack of knowledge by Australian consumers of food regulation [35] or alternately greater concern with regulatory than monitoring functions.

In relation to demographic characteristics female participants viewed personal responsibility and consumer groups as 'Very important' in monitoring food safety and quality when compared with men ( $\mathrm{OR}=1.9, p<0.001$ and $\mathrm{OR}=1.8, p<0.001$ respectively). This finding reflects outcomes of similar studies. Worsley and Scott in earlier Australian research found that women were significantly more concerned with all aspects of food safety than men [36]. Poppe and Kaerjnes in survey research across seven European countries found, for example, that women were significantly less likely to consider specific food items as 'very safe' to eat when compared with men. This finding may reflect the gendered nature of food provision [30]. Mallyon et al. [37] note that responsibility for food provision and the healthiness of diet is still viewed as a female responsibility a perspective which is promoted by women's magazines which feature articles championing healthy eating [38].

The age of participants is also related to perceptions of the importance of agencies in monitoring food safety with younger participants assigning less importance to view food monitoring than older participants. Comparison of data across the index of all monitoring agencies demonstrates that people under 30 report food monitoring as 'Very important' 2 to 3 times less often than older respondents with the greatest disparity noted for participants over 60 years (OR $=3.2, p<0.001$ ). Disparity between respondents under 30 and older respondents was most evident in the importance placed upon food scientists and the role of local government. A lack of concern with food safety by people under 30 reflects previous studies which found that cost, time, health and appearance were motivators of food choice in people aged 18-30 years [39,40]. Long term health is of less consequence to younger participants resulting in greater risk taking in terms of food choice and health [28,41-43].

Significant but contradictory differences were found in relation to the number of people and presence of children within the household. While living in household with more than 5 or more people 
was positively associated with attributing importance to all monitoring agencies ( $\mathrm{OR}=2.9, p<0.01$ ) compared with people living alone, number of children within the household was negatively associated with the placement of importance on food monitoring. Households with more children viewed the role of federal government, the media and consumer groups as 'Very important' in monitoring food safety less often than households with no children. This finding is unexpected and contradicts previous studies. Kornelis et al. found for example, that people with dependent children have a greater interest and greater use of food safety information [44] while Henderson et al. found that the presence of dependent children was associated with greater concern with food safety and healthy eating [45]. This may reflect greater self-regulation of food safety as opposed to reliance upon external agencies however this is not reflected in the importance placed on self-regulation by families with more dependent children. This is a finding that may require further exploration.

\section{Strengths and Limitations}

There were a number of issues related to the sampling frame and final sample that are worthy of mention. Firstly, the EWP used as our sampling frame only lists households with a landline. Dilman et al. [46] note that the growing use of mobile phones has contributed to decreasing responses rates for surveys administered via telephone potentially biased the sample towards older homeowners who are more likely to maintain a landline. Secondly, whilst a response rate of $41.2 \%$ is acceptable for CATI surveys, it suggests a need for caution in generalising these results to the wider population, primarily due to non-response bias [47]. Indeed, response rates are declining in surveys based on all forms of interviewing [48,49] possibly as a result of people becoming either more active in protecting their privacy or less engaged or interested in research [46]. Finally, as the survey replicated questions utilised within the European Food and Trust survey where industry self-regulation is more widespread and accepted, the survey did not contain questions about the importance of industry self-regulation which has been found to be less acceptable to Australian consumers [25,50]. Notwithstanding these potential limitations, the strength of this study includes the random sampling, the large sample size and the weighted data.

\section{Conclusions}

This study has explored the importance placed on the monitoring of food safety by different agencies. The research demonstrates that while food safety issues are not accorded great importance by the sample as a whole, that personal and public governance of food safety are viewed as most important. This is at odds with the risks posed by food borne pathogens and reflects what Redmond and Griffith call 'optimistic biases' in relation to food safety arising from a belief in a personal capacity to prevent food poisoning [4]. The importance placed upon the role of the Federal government contradicts trends within the governance of food safety which favour multi-level governance and co-regulation. Contrary to expectations participants in this study did not place importance upon the role of State and Local governments, suggesting limited knowledge of their roles. In addition men, people under 30 and those in remote areas consistently place less importance on food safety monitoring, potentially placing these groups at risk. This is a finding that may require further exploration. 


\section{Acknowledgements}

Funding for this research was provided through an Australian Research Council (ARC) Discovery grant on Food \& Trust.

\section{Conflict of Interest}

The authors declare no conflict of interest.

\section{References and Notes}

1. Paul Mead, Laurence Slutsker, Vance Dietz, Linda McCaig, Joseph Bresee, Craig Shapiro, Patricia Griffin, and Robert Taux. “Food-related illness and death in the United States.” Emerging Infectious Diseases 5 (1999): 607-25.

2. Graham Bentham, and I.H. Langford. "Environmental temperatures and the incidence of food poisoning in England and Wales.” International Journal of Biometeorology 45 (2001): 22-26

3. Romsey Australia. "Worldwide increases in food borne illnesses.” 2009. http://home.iprimus.com.au/ foo7/badfood.html.

4. Elizabeth Redmond, and Christopher Griffith. "Consumer perceptions of food safety risk, Control and responsibility.” Appetite 43 (2004): 309-13.

5. John Coveney. "Food \& Trust in Australia: Building a picture.” Public Health Nutrition 11 (2008): 237-45.

6. Sandra Buchler, Kiah Smith, and Geoffrey Lawrence. "Food risks, old and new: Demographic characteristics and perceptions of food additives, regulation and contamination in Australia." Journal of Sociology 46 (2010): 353-74.

7. Florence Bergeaud-Blacker, and Maria Ferrenti. "More politics, stronger consumers? A new division of responsibility for food in the European Union.” Appetite 47 (2006): 134-42.

8. Tim Lang, and Michael Heasman. Food Wars: The Global Battle for Mouths, Minds and Markets. London: Earthscan, 2004.

9. Michele Veeman. "Changing consumer demand for food regulations." Canadian Journal of Agricultral Economics 47 (1999): 401-09

10. Roberta Sassatelli, and Alan Scott. “Novel Food, New Markets and Trust Regimes.” European Societies 3 (2001): 213-44.

11. Corinne Wales, Mark Harvey, and Alan Warde. "Recuperating from BSE: The shifting UK institutional basis for trust in food.” Appetite 47 (2006): 187-95.

12. Doris Fuchs, Agni Kalfagianni, and Tetty Havinga. "Actors in private food governance: The legitimacy of retail standards and multistakeholder initiatives with civil society participation.” Agriculture and Human Values 28 (2011): 353-67.

13. Ladina Caduff, and Thomas Bernauer. "Managing risk and regulation in European food safety governance.” Review of Policy Research 23 (2006): 153-68.

14. Bente Halkier, and Lotte Holm "Shifting responsibilities for food safety in Europe: An introduction.” Appetite 47 (2006): 127-33. 
15. Marian Garcia Martinez, Andrew Fearne, Julie Caswell, and Spencer Henson. "Co-regulation as a possible model of food safety governance: Opportunities for public private partnership.” Food Policy 3 (2007): 299-314.

16. Marion Healy, Simon Brooke-Taylor, and Peter Liehne. "Reform of food regulation in Australia and New Zealand.” Food Control 14 (2003): 357-65.

17. Jill Hobbs, Andrew Fearne, and John Spriggs. "Incentive structures for food safety and quality assurance: An international comparison.” Food Control 13 (2002): 77-81.

18. Gary Sacks, Boyd Swinburn, and Mark Lawrence. "A systematic policy approach to changing the food system and physical environments to prevent obesity.” Australia and New Zealand Health Policy 5 (2008): 5-13.

19. Ray Winger. “Australia New Zealand Food Standards code.” Food Control 14 (2003): 355.

20. Kari Elvbakken, Per Lægreid, and Lise Hellebø Rykkja "Regulation for safe food: A comparison of five European countries.” Scandinavian Political Studies 31 (2008): 125-48.

21. Richard Souness. "HACCP in Australian food control.” Food Control 11 (2000): 353-57.

22. Tanya Martin, Elizabeth Dean, Brigid Hardy, Tony Johnson, Fiona Jolly, Fiona Matthews, Ian McKay, Richard Souness, and Jenny Williams. "A new era for food safety regulation in Australia.” Food Control 14 (2003): 429-38.

23. Jim Gruber, Simon Brooke-Taylor, Julie Goodchap, and Dean McCullum. "Regulation of food commodities in Australia and New Zealand.” Food Control 14 (2003): 367-73.

24. Food Standards Australia New Zealand [FSANZ]. Consumer Attitudes Survey 2007: A Benchmark Survey of Consumers' Attitudes to Food isSues. Canberra: Food Standards Australia New Zealand, 2008.

25. Julie Henderson, John Coveney, and Paul R. Ward. "Who regulates food? Australians' perceptions of responsibility for food safety.” Australian Journal of Primary Health 16 (2010): 334-51.

26. John Tulloch, and Deborah Lupton. "Consuming risk, consuming science: The case of GM foods.” Journal of Consumer Culture 2 (2002): 363-83.

27. Lynn Frewer, Chaya Howard, Duncan Hedderly, and Richard Shepherd. "Methodological approaches to assessing risk perceptions associated with food-related hazards.” Risk Analysis 18 (1998): 95-102.

28. Louise Holmberg, John Coveney, Julie Henderson, and Samantha Meyer. "What should primary health care practitioners know about factors influencing young people's food choice?” Australasian Medical Journal 1 (2010): 156-63.

29. Peter Williams, E. Stirling, and N. Keynes. "Food fears: a national survey on the attitudes of Australian adults about the safety and quality of food Asia Pacific.” Journal of Clinical Nutrition 13 (2004): 32-9.

30. Christian Poppe, and Unni Kjærnes. Trust in Food in Europe: A Comparative Analysis. Olso: National Institute for Consumer Research, 2007.

31. Julie Henderson, John Coveney, Paul R. Ward, and Anne W. Taylor. "Farmers the most trusted part of the Australian food chain: results from a national survey of consumers." Australian and New Zealand Journal of Public Health 35 (2011): 319-24. 
32. Anne W. Taylor, A. John Coveney, Paul R. Ward, Elenora Dal Grande, Loreen Mamerow, Julie Henderson, and Samantha Meyer. "The Australian Food and Trust Survey: Demographic indicators associated with food safety and quality concerns.” Food Control 25 (2012): 476-83.

33. David Hosmer, and Stanley Lemeshow. Applied Logistic Regression, 2nd ed. New York: John Wiley \& Sons, Inc, 2000.

34. Andy Field. Discovering Statistics using SPSS, 3rd ed. London: Sage Publications, 2009.

35. Anna Wilcock, Maria Pun, Joseph Khanona, and May Aung. "Consumer attitudes, knowledge and behaviour: A review of food safety issues.” Trends in Food Science and Technology 15 (2004): 56-66.

36. Anthony Worsley, and Victoria Scott. “Consumers' concerns about food and health in Australia and New Zealand.” Asia-Pacific Journal of Clinical Nutrition 9 (2000): 24-32.

37. Anna Mallyon, Mary Holmes, John Coveney, and Maria Zadoroznyj. "I'm not dieting, 'I'm doing it for science': Masculinities and the experience of dieting.” Health Sociology Review 19 (2010): 333-42.

38. Tanja Schneider, and Theresa Davis "Fostering a hunger for health: Food and the self in 'The Australian Women’s Weekly’” Health Sociology Review 19 (2010): 285-303.

39. Stephanie Chambers, Alexandra Lobb, Lorrie Butler, and W. Bruce Traill. "The Influence of age and gender on food choice: A focus group exploration." International Journal of Consumer Studies 32 (2008): 356-65.

40. Marie Marquis. "Exploring convenience orientation as a food motivation for college students living in residence halls.” International Journal of Consumer Studies 29 (2005): 55-63.

41. Deborah Lupton. "Lay discourses and beliefs related to food risks: An Australian perspective." Sociology of Health and Illness 27 (2005): 448-67.

42. Judith Green, Alizon Draper, and Elizabeth Dowler. "Short cuts to safety: Risk and 'rules of thumb’ in accounts of food choice.” Health Risk and Society 5 (2003): 33-52.

43. D. Neumark-Sztainer, M. Story, C. Perry, and M. Casey. "Factors influencing food choices of adolescents: Findings from focus group discussions with adolescents." Journal of the American Dietetic Association 99 (1999): 929-37.

44. Marcel Kornelis, Jenneke de Jonge, Lynn Frewer, and Hans Dagevos. "Consumer selection of food-safety information sources.” Risk Analysis 27 (2007): 327-35.

45. Julie Henderson, Paul R. Ward, John Coveney, and Anne W. Taylor " "Health is the number one thing we go for': Healthism, citizenship and food choice.” In The Future of Sociology. Paper presented at TASA conference, Canberra, Australia, 1-4 December 2009.

46. Don Dilman, Glen Phelps, Robert Tortora, Karen Swift, Julie Kohrell, Jodi Berck, and Benjamin Messer. "Response rate and measurement differences in mixed mode surveys using mail, telephone, interactive voice response (IVR) and the internet." Social Science \& Medicine 38 (2009): 1-18.

47. R. Curtin, S. Presser, and Eleanor Singer. "Changes in telephone survey non-response over the past quarter century.” Public Opinion Quarterly 69 (2005): 87-88.

48. Robert Groves. "Nonresponse rates and nonresponse bias in household surveys.” Public Opinion Quarterly 70 (2006): 646-75. 
49. Paul R. Ward, Jill Thompson, Rosemary Barber, Christopher Armitage, Jonathon Boote, Cindy Cooper, and Georgina Jones. "Critical perspectives on 'consumer involvement' in health research: Epistemological dissonance and the know-do gap.” Journal of Sociology 46 (2010): 63-82.

50. Janet Hoek, and Bronwyn King. "Food advertising and self-regulation: A view from the trenches.” Australian and New Zealand Journal of Public Health 32 (2008): 261-65.

(C) 2013 by the authors; licensee MDPI, Basel, Switzerland. This article is an open access article distributed under the terms and conditions of the Creative Commons Attribution license (http://creativecommons.org/licenses/by/3.0/). 